\title{
COOPERATION OR CONFLICT? THE NATURE OF THE COLLABORATION OF MARKETING AND SALES ORGANIZATIONAL UNITS
}

\author{
Anikó Kelemen-Erdős ${ }^{1}$, Adél Molnár² \\ ${ }^{1}$ Óbuda University, Budapest, Hungary, kelemen.aniko@kgk.uni-obuda.hu \\ ${ }^{2}$ Óbuda University, Budapest, Hungary, molnar.adel.ma@gmail.com
}

\begin{abstract}
Research purpose. The marketing and sales activity of a company can involve synergy, and coordinated operations can contribute to the success of the enterprise. However, the operations of the former departments often rely on individual successes, which boost conflicts of interest and hinder collaboration. The main aim of the research described in this paper is to explore the areas and focal points of collaboration and conflict in order to highlight the tools that can contribute to enhancing alignment and effectiveness. A further goal is to examine the relationship between marketing and sales and their appraisal of each other.
\end{abstract}

Design/Methodology/Approach. The empirical research applied three qualitative focus group interviews among marketing and sales employees in different positions at multinational enterprises. Results are analyzed using grounded theory methodology.

Findings. The research highlights the process interfaces between marketing and sales activities and results in the identification of the competence and attitude gaps in their cooperation. Marketing is an entire corporate function, although without knowledge of customers and markets and experience of sales it is unable to foster the innovation processes which, along with cost and time management, result in "efficient and effective corporate operations" as the core category of grounded theory. The outcomes presented here are novel in relation to how they highlight that collaboration should be grounded on clearly defined corporate targets and the engagement of employees with these, as well as supportive and reinforcing manager-subordinate relationships. However, the prioritization and appraisal of the departments of organizational units appears to be dependent on the position and information coverage of employees. Having more information increases the latter's ability to better evaluate other fields of business. In addition to these issues, the explored discrepancies refer mainly to the information transfer process, suggesting that the external and internal accessibility and availability of information to departments is crucial. Information that is accompanied by accurate predictions about market demand and local needs adjustment enables successful innovation and helps create marketable, innovative, well-differentiated, high-quality, valuable products, the availability of (and customer responses to) which is required for the successful performance of a company. The former may be delivered through the contribution of both organizational units. Building and reinforcing human relationships can facilitate these processes.

Originality/Value/Practical implications. In comparison to other research on this topic, the present study applies focus group interviews as a novel method to create a deeper and more thorough picture of the related processes. The model which emerges from the analysis of results highlights problems with practical management that can contribute to the development of a more efficient management system. Employees can be trained to decrease the identified discrepancies, while rewarding positive attitudes to collaboration contributes to their alignment.

Keywords: Corporate performance; Organizational behavior; Marketing and sales collaboration; Sales and marketing interface; Grounded theory.

JEL codes: D23; L20; M30.

\section{Introduction}

The classic structure of an organization includes departments of marketing and sales. However, the weight of these fields among all company functions is different. Marketing-oriented companies allocate marketing tasks to all organizational units, whereas (less widespread) sales-oriented companies subordinate marketing to sales. Thus, conflicts may emerge because of such imbalances, while the related departments are often more interested in their own market success than the company's. Such disagreement can be so serious that it is often defined as "war" (among others, Kotler et al., 2006, 
Johnson \& Boeing, 2016). Accordingly, marketing specialists should endeavor to enhance their connection to salespeople.

At micro and small enterprises, marketing and sales are not separate departments and, in certain cases, can involve only one employee. In spite of the quantity of information about the operation of these areas, there are still shortcomings with such collaboration. Nevertheless, company success is determined by their performance, and synergy created by closer cooperation may contribute to raising overall effectiveness. The efficiency of organizational units is typically measured on an individual basis, rather than as an integrated function, but greater collaboration may create a more innovative system in which profit can be increased. However, practical solutions and thus the related mechanisms of application differ significantly depending on internal and external factors such as the features of the market and company (Homburg et al., 2017).

The aim of the research described in this paper is to highlight potential internal organization- and process-related factors and fields of marketing and sales cooperation that may enhance the effectiveness of enterprises. A further target is to explore the nature of their relationship at multinational enterprises. The focus on multinational companies enables the wider generalization of results, although cultural differences may exist.

Following a secondary comparative analysis, a conceptual model of routine (daily) activities is constructed whereby the cycles in which both organizational units should simultaneously exist or cooperate are emphasized. On the basis of this model, we inquired of professionals using expert focus groups about potentially problematic areas and the points at which the knowledge of other departments should be integrated. This research problem is commonly referred to and has been the subject of many doctoral dissertations, such as those of Micevski (2015), Kelly (2017), and Watson (2017).

The present research accords with the interest of companies because it can contribute to developing their operations, not only in terms of productivity, but also in terms of fostering a positive shift in social relationships. In addition to such forward-looking changes, it is important to identify hindering factors which the company can overcome to improve its potential for development. However, the unpredictability of human factors involves the danger that such forms of cooperation will be opposed or, in the worst case, lead to the intensification of internal competition.

\section{Literature Review}

According to Homburg et al. (2017), more than 68 percent of managers find that the collaboration of marketing and sales is crucial in research and development throughout the new-product development process. However, Ernst et al. (2010) investigated foremost the relationship between marketing and sales as a cross-functional area in relation to innovation-based procedures. The authors describe crossfunctionality in two dimensions: behavior (in terms of the method and intensity of knowledge interfaces) and the attitude toward a common vision and targets among participating departments. Micevski (2015) supports the relevance of such cross-functionality and stresses the role of management in overseeing the relevant interfaces. This study attempts to determine those internal corporate factors that may be the basis of a fruitful collaboration.

Following an investigation of marketing and sales functions, Homburg and Jensen (2007) point out that long-term strategies and thinking of marketing in terms of market segments create a distance from the customer, which is why a short-term, direct focus on customers (i.e., market-linked sales) can provide valuable information for use in organizational processes. How companies and customers get in touch with each other and whether and how they communicate and react (the so-called sensemaking) can be the cause of dysfunctions and turbulence (Malshe et al., 2016). The roots of conflict are located in normative and affective differences in the sales and marketing interface, and its contribution to value creation (Kelly, 2017). In the context of the former, "normative" refers to the diverse aims, opportunities, and experiences of operating and results, whereas "affective" pertains to the variety of insights, views, and opinions. 
Perceptions can differ depending on situational and human traits and may hinder preparation for and identification of algorithms for solving interactivity-based problems. However, these are essential for fostering work processes.

Marketing and sales collaboration is dependent on multiple factors, which are summarized in Table 1. Organizational structure and its formalization determine collaboration (Keszey \& Katona, 2016). In addition, informal communication processes as well as the company's philosophy and management style can be supportive of the latter. In 2009, the highly innovative Hungarian start-up Prezi was founded, employing a loose, informal atmosphere which supports emerging ideas and collaboration. It now has more than hundred million online users worldwide.

The distinction between marketing and sales as organizational functions is fading as these areas of activity increasingly tend to be integrated (Keszey \& Biemans, 2015, Keszely \& Katona, 2016, 2017) and the empowerment of sales activity increases the benefit to companies in terms of innovation and efficiency (Keszey \& Katona, 2017). The importance of effective collaboration and supporting behavior between organizational units is essential for a company's success (Kotler et al., 2006, Homburg \& Jensen, 2007, Ernst et al., 2010, Malshe \& Biemans, 2015, Keszey \& Biemans, 2015, Keszely \& Katona, 2016, Homburg et al., 2017).

Marketing activities are strategic in nature and strive to meet consumer needs. In this strategic process, research and development is supported by collaboration between marketing and sales. Companies cannot be confined by the need for a marketing-oriented process; this approach should be present from the stage of initial ideas to the post-buying process (Kotler et al., 2006, Homburg \& Jensen, 2007, Ernst et al., 2010, Homburg et al., 2017). Customer-oriented corporate leadership is a profitable strategy (Kotler et al., 2006, Malshe \& Biemans, 2015, Keszey \& Katona, 2016), which is why marketing recognizes the importance of sales experience, including knowledge about customers which arises from having a direct connection with them (Kotler et al., 2006, Homburg \& Jensen, 2007, Ernst et al., 2010, Malshe \& Biemans, 2015, Homburg et al., 2017).

Data about market wants and needs are constantly refreshed, while marketing information collected by sales managers is processed by marketing departments and supplemented with data and research-based information from other sources, so a competitive service and product design is created (Keszey \& Katona, 2016).

Information from salespeople is updated and made relevant, as during their activities they may immediately recognize the appearance of demands, although it is important to emphasize that this information becomes valuable only when it is effectively used in product development (Kotler et al., 2006, Keszey \& Katona, 2016). The question may arise as to what obstructs data flow when employees pursue a common purpose (i.e., market success). Such obstacles are to be found in the conflict between organizational units and the underestimation of "the other" (Kotler et al., 2006, Malshe \& Biemans, 2015, Keszey \& Biemans, 2015). By striving to prevent or eliminate these problems, a company can increase its chances of success.

In the modern corporate environment, the cooperation of sales and marketing activities can create competitive advantage and may increase customer satisfaction (Keszey \& Biemans, 2015, Keszey \& Katona, 2016) and business performance (Le Meunier-FitzHugh \& Piercy, 2007). The basis of the marketing and sales relationship is both economic and social in nature (Kotler et al., 2006, Keszey \& Biemans, 2015, Keszey \& Katona, 2016). 


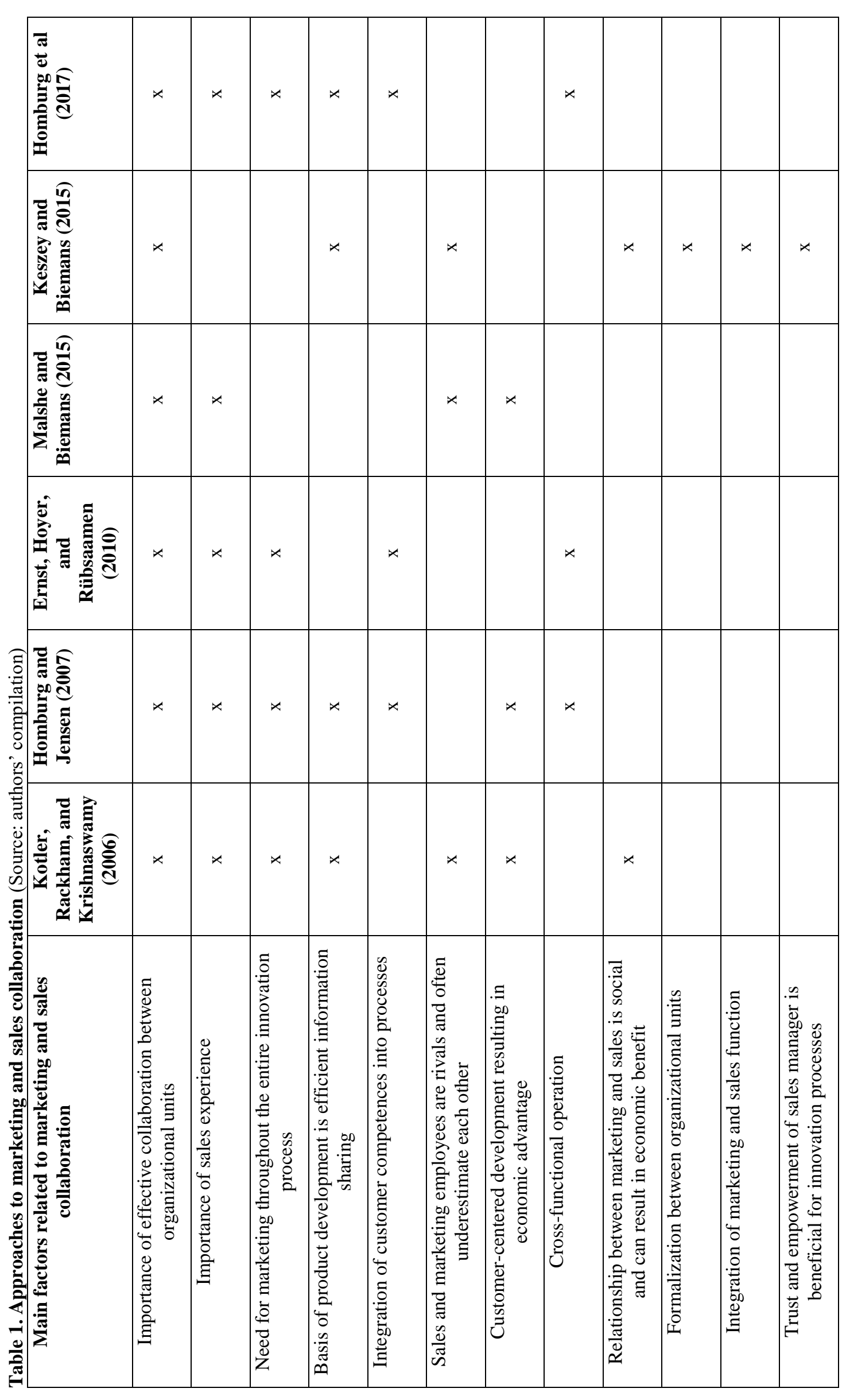

5 
Secondary sources suggest a few possible solutions to the problem. Salespeople should be incorporated into marketing processes and work together with marketing people. This can improve engagement with customers and the respective experts at the same time (Kotler, 2004). The collaboration of marketing and sales can be supported by creating less hierarchical organizational processes, thus empowering managers, and holding external training for employees which intensifies engagement and connections (Keszely, 2014). Le Meunier-FitzHugh and Piercy (2007) point out that collaboration can be fostered by integrating factors, other enablers, and management methods. Le Meunier-FitzHugh and Piercy (2007) and Watson (2017) conclude, however, that collaboration is not enough: Marketing and sales should be engaged at a higher level, suggesting the better integration of departments. In their framework, integration occurs through communication, regulated business operation, organizational learning, measurement of efficiency, customer orientation, and strategic and marketing planning, whereas decision support systems should also be effective. Le Meunier-FitzHugh and Piercy (2007) add that management can define aligned targets and a vision, which can contribute to cocreation while integrating the resources and competences of marketing and sales. In addition to management support, the authors state that facilitating cross-functional and integrated work processes can foster collaboration. In the case of retailing, trade marketing and category management are toolkits for fostering the alignment of marketing and sales units (Dewsnap \& Jobber, 2009).

\section{Methodology}

An explanatory qualitative research method was considered appropriate for a closer examination of the collaboration of the fields of marketing and sales. By approaching the topic this way, novel ideas are allowed to contribute to identifying focal areas, problems, and solution agendas. Focus groups support idea generation (Malhotra \& Birks 2007), although people behave differently in group circumstances (Kidd \& Parshal, 2000) because their attitudes and behavior are influenced by other participants and may converge because of group conformity.

The present research applied expert focus group interviews because experts' opinions represent a relevant sample, thus increasing reliability. Focus groups allow the presentation of conflicting views and opinions and encourage compromises. In spite of the former, focus group results are not representative, although companies sometimes rely on their results (Kotler, 2004). Any identified correlations should be further tested, although generalizability is limited because of the sample size and the sampling method. However, the aim of such research is not to generate exact "answers" but rather "to bring meaning to a situation" (Rabiee, 2004, p. 657).

Focus groups may appear to be easy to arrange, but are characterized by the production of chaotic, diverse, weakly transparent data sets which do not support the analytical process (Kidd \& Parshal, 2000, Rabiee, 2004). Even the organization of expert focus groups may encounter difficulties because it is challenging to identify times and locations at which busy managers can come together. This is why mini focus groups were applied in the present research, leaving more space for thought but potentially limiting the variety of answers, already narrowed by the time that was available.

Focus groups have already been applied in research with a similar scope. Karlíãek et al. (2014) conducted two focus groups to investigate marketing effectiveness-enhancing opportunities, concluding that departments should be more sympathetic to each other, because anyone can make a mistake.

In order to obtain adequate answers, experienced participants should be invited to participate. Applying Knodel's (1993) concept of common characteristics, which refers to the common traits of constructed groups, three conflict groups were organized to highlight the main conflict areas and potential solutions for marketing and sales departments. In such cases, conflicts may be twofold: Such groups contain participants from both organizational units, potentially increasing intergroup conflict, and may also be diverse in terms of participant age and position which can create intragroup conflict. Intergroup conflict refers to conflict which arises due to the inappropriate interaction of different teams, whereas intragroup conflict occurs in the form of relationship- or task-based conflicts between the members of a group (Rout \& Omiko, 2007). In our research, as a break variable (Knodel, 1993), company affiliation can be defined because the members of the first group worked at the same company, whereas members of the second and third groups were employed at different companies. 
In our sample, the first focus group consisted of three women from the same company: a sales manager (46 years old), a marketing manager ( 31 years old), and a sales assistant ( 21 years old). The managers had several years of experience, which could have resulted in an asymmetrical situation, but the small company (23 employees) has a positive atmosphere, so interviewees were able to speak freely and enthusiastically about the company's system.

The second group was recruited with respect to company differences in order to minimize the effects of dependency. However, variability in age and gender may have played a more significant role in this group because it included three men and a woman from separate companies: a former chief executive officer and marketing director (72, male), a marketing manager (43, female), a sales manager (32, female), and a sales assistant ( 21 , female). The atmosphere was more neutral in this second focus group, although participants were curious and interested in each other's thoughts.

The third group included five career-starter women with a few years' working experience who were employed at different companies. Their positions were as follows: two marketing assistants (both 23 years old), a saleswoman (27 years old), and two marketing trainees (23 and 25 years old). During the focus group interview, the atmosphere was informal and friendly, although participants noted their dissatisfaction with the working environment.

Cross-validation of the results requires that the outcomes should fit with the theory (Fern, 2001). On one hand, this approach can help with understanding and interpreting findings, but on the other hand, it limits the research framework. For this reason, the research described in this paper applied crossvalidation at the beginning of the research and, throughout the analyses, relied on internal validity regarding theoretical constructs. To enhance their relevance, the research questions were based on findings from secondary literature:

K1. How do marketing and sales departments mutually appraise each other?

$\mathrm{K} 2$. Which factors can enhance the successful collaboration of marketing and sales in a company?

K3. What difficulties emerge during the information transfer process between marketing and sales?

In order to obtain accurate results, a semistructured guide was used, whereas with some questions the moderator let the conversation flow to obtain deeper understanding of the topic.

Grounded theory was applied as a data analysis method. This approach can contribute to mapping and summarizing the results in a systematic, scientifically accepted way (Glaser \& Strauss, 1967, Charmaz, 2006). However, grounded theory was not applied to sampling, but to interviewing. After conducting the interviews, the questions were supplemented by novel ones, allowing theory to emerge. The research process included gathering data from three interviews (the first one lasting 55 minutes, and the second and third both 1 hour and 30 minutes), which resulted in a 12-page transcript. The transcript was coded line by line, then the codes were selected following Miles and Huberman's (1994) suggestions. Codes were classified into subcategories which together created the main category which was defined as "efficient and effective corporate operation." In addition to grounded theory, a few highlighted quotations include narratives which, by providing content, support the findings.

\section{Results}

At the beginning of the grounded theory analysis, "marketing and sales collaboration" appeared to be the core category regarding the research aim, but the results also extended beyond the relationship and connection between the two organizational units, and were closely interrelated with the company's performance. This is why "efficient and effective corporate operation" was specified as the broader category.

An important input of the core category which influences the overall performance of the company is the adaptation of the targets of the parent company to the subsidiary company. Gaps may occur in the communication of parent company's targets in spite of cultural differences and discrepancies, which are strongly related to information delivery and communication retention and often result in dependency. 
The appraisal of marketing and sales departments (K1) appears to be dependent on the respondents' position within the company. Employees in managerial positions are more likely to think in terms of achieving common company goals, whereas others are not motivated by this at all, while those in starter positions have no knowledge about such clearly defined targets. Moreover, those who have worked in several areas are able to use experience gained elsewhere to make suggestions for improving the performance of the other department. The broader the picture a person has of a given area, the more the person seems to consider his or her department to be important, and vice versa. Thus, individuals who have more information are better positioned to acknowledge the other work of other units and to evaluate other fields more positively. The nature of often rigid manager-subordinate relationships can be the background to this challenge. In such cases, there is often a lack of support and reinforcement.

The results suggest a consensus that the relationship between the two organizational units is basically supportive and mutually reinforcing. The work of salespeople is supported by well-established marketing activities. This observation refers not just to products or services, but the "selling" of corporate identity and brand equity are considered just as important as selling in a traditional sense: "Sales managers sell products, the marketing manager sells the company," stated a sales assistant. This suggests that marketing maintains and can ground the profitable development of a company through which innovation can occur. The efficiency of product and service distribution can always be improved, and the constant pursuit and development of this is indispensable.

Information flow, an important factor in collaboration (K2), was emphasized by every participant, suggesting that information transfer is considered a highlight of shared activity. The focal points of such information, which were identified as subcategories, can be classified into two main areas: external and internal information, the factors of which are included in Table 2. Both units require access to such information in an appropriate form and at the correct time to support efficient corporate operations. An internal information system can be a platform for information flow. Communication takes place via online surfaces which facilitate its retrieval and storage. However, in reality there is sometimes a lack of information availability.

Both units transmit information to each other and to the decision-making level, and ultimately to leaders. The decision-making role of managers is limited, so they focus on decision-making proposals. Information is collected on the basis of current trends and market situations. Development decisions are tailored to business plans and to marketing and sales strategies.

Table 2. Focus of Information Regarding Marketing and Sales Departments' Relationships (Source: authors' compilation according to focus group feedback)

\begin{tabular}{|l|l|}
\hline External information & Internal information \\
\hline Market situation and trend analysis & Forecasts \\
\hline Consumer demand & Sales data \\
\hline Competitors' activities & Customer satisfaction measures \\
\hline Domestic and international innovation & Statistics and statements \\
\hline Current research findings & Cross-functional activities \\
\hline Statistics & Announcements \\
\hline $\begin{array}{l}\text { Customer responses (offline and online via social } \\
\text { communities) }\end{array}$ & \\
\hline
\end{tabular}

The core processes which drive the success of the company are initiatives that sustain integrated marketing and innovation processes at a strategic level, along with sales ideas and support that arises from personal connections with customers, knowledge, and experience. Cross-functionally and at an operative level, cost and time optimization should be taken into account, the factors of which may promote more efficient and effective corporate operations (Fig. 1). These results confirm previous 
knowledge about the role of marketing and sales (Homburg \& Jensen, 2007, Le Meunier-FitzHugh \& Piercy, 2007, Ernst \& Hoyer \& Rübsaamen, 2010, Homburg et al., 2017).

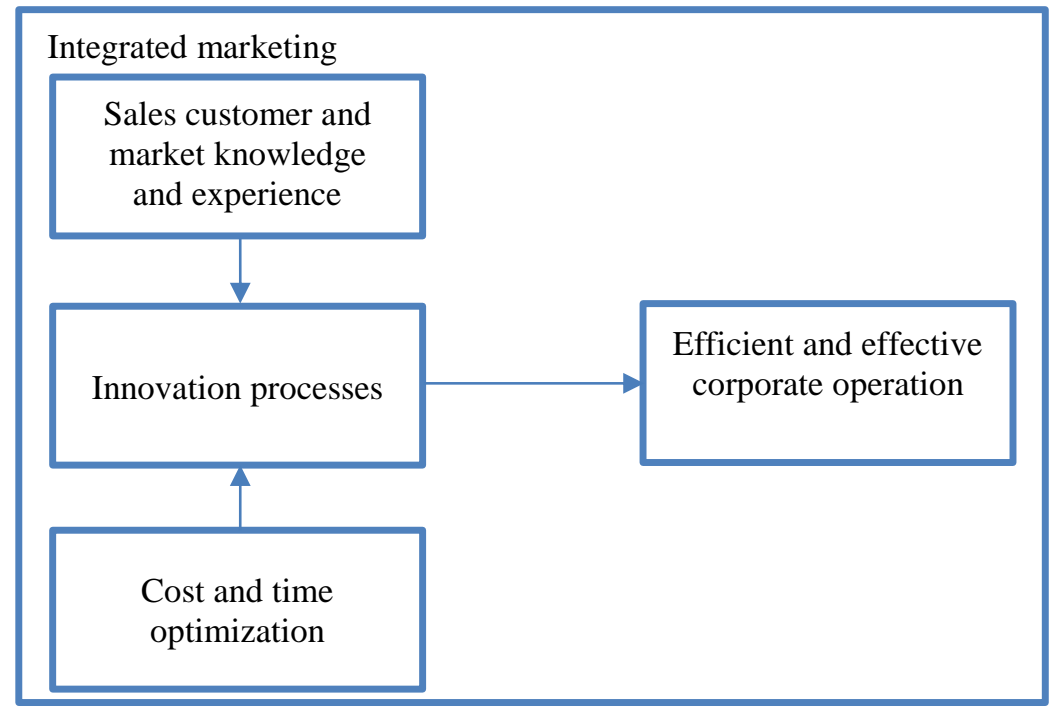

Fig. 1. The role of marketing and sales in efficient and effective corporate operations (Source: authors' construction according to focus group feedback)

Selective coding with grounded theory resulted in the creation of subcategories related to the main category, thus the final grounded theory emerged as depicted in Figure 2. A novel approach is that collaboration should begin with the provision of corporate conditionality, which should rely on embedded corporate targets and employers' engagement to these. Management should support employees to encourage their value creation and contribution. The outcomes can be interpreted in line with the following model of a streamlined new product development cycle:

a. Idea collection and planning phase

b. Production phase

c. Distribution phase

d. Postpurchase phase

Designing research on the basis of needs assessment is the foundation for future success or failure. Products and services are constantly being managed and monitored from conception to after-purchasing customer responses. In the innovation processes, all units should be treated as a single corporate entity: "We strengthen each other, we work together for one purpose, because otherwise it wouldn't work," stated a sales assistant.

In terms of analyzing the role of sales and marketing collaboration at the level of idea gathering, "information dimensions" (external and internal) as the source of innovation and as process support emerged as a subcategory, in which availability and accessibility are considered crucial. Information forms the basis of "accurate market demand predictions," which facilitates competitive advantage. However, "real market trends" and "local needs" should be taken into account, which support sales. In a competitive environment, "innovation constraints" push the company to develop its offerings. 


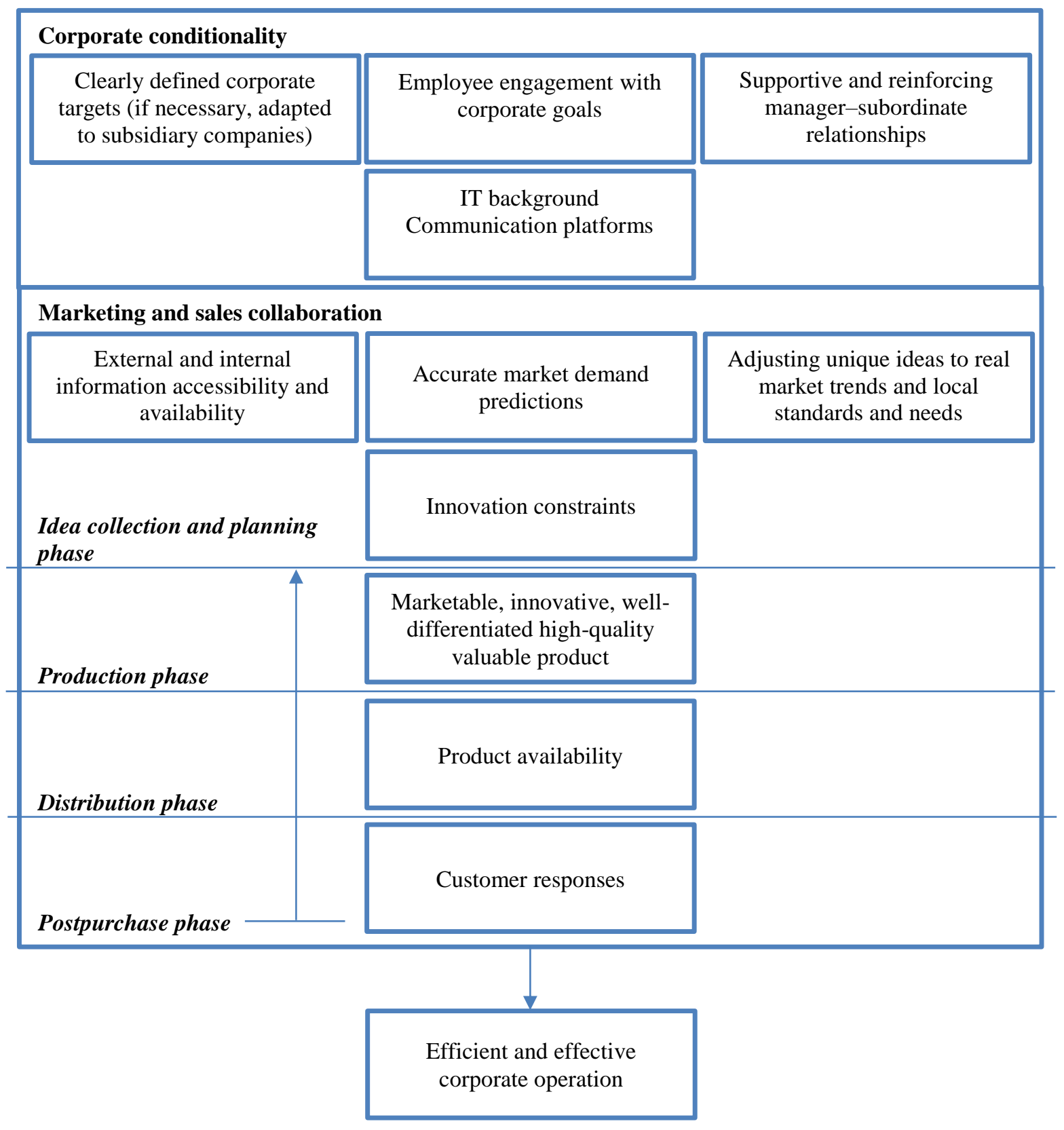

Fig. 2. Areas for the collaboration of marketing and sales for supporting efficient and effective corporate operations: results of grounded theory (Source: authors' construction according to focus groups)

At the production level, considerations such as marketability, innovation potential, and differentiation aligned with high-quality and affordable price can foster the penetration of the product or service. Moreover, distribution should be intensive regarding target-group location. Customer responses may be identified directly as sales, but such valuable information should be shared with marketing departments to support innovation regarding customer needs. At the phase of postpurchase, customer feedback should be used as input information for the development process.

The weak points of collaboration (K3) appear to be a deficient information technology background and communication processes, poor information, misunderstanding of other department- or expert needs, tardiness, or the concealing of information. Despite the planning and road-mapping of activities, failures do occur, for which a scarcity of time is often the reason. "We produce things for the day before yesterday that we just found out today," claimed a marketing manager. 
Interviewees from different companies highlighted the fact that a lack of workforce hinders the faster development of their company. Employee fluctuation creates obstacles, even causing collaborative processes to become stuck. Too much emphasis on marketing strategy formation and an impatience for sales may be due to customers' diverse requests.

In many cases, employees do not know much about the complexity of other company areas, so they tend to underestimate the amount of work that takes place in less well-known departments. However, sometimes routine activities and late response to market events are sources of failure. An experienced CEO drew attention to the need to "...learn from mistakes and avoid routine [...] There is always something going on and nothing is ever going on exactly according to the plan." Thus, work must be regularly monitored and employees should acknowledge and learn from their mistakes.

\section{Conclusions}

The findings described herein can be recommended to organizations in order to enhance their organizational and market performance. The research results reflect the importance of transparent hierarchical structure, coordination, the indispensability of automating support systems, and the market advantage of innovation-centered thinking. With the employment of the right resources, along with technical and technological support, a foundation may be created that fosters information flow, as this is of critical importance to market success.

Improving human relationships can contribute to better understanding and appreciating the knowledge, skills, and capabilities of employees and more positive appraisals of the personalities and work of others and other areas. In case of career starters, mentor programs and the definition of individual development paths linked with rotation can help to boost self-confidence and reinforce self-esteem, which can trigger the integration of the former into the corporation and foster trust in other colleagues. Supportive relationships must be cultivated and maintained to improve overall efficiency. Developing and deepening both personal relationships and social relationships is required for both individuals and groups to achieve success. Employees should be trained to become more open to innovation and teamwork for which creativeness and (sometimes) risk-taking behavior are necessary.

Further research into other departments that use the same analytical method could help to create strategies for the development of the broader organizational system. Only one area should be changed at a time, and only to the extent to which employee and organizational behavior can be modified. Chaotic change processes often result from simultaneous attempts at full-scale reform wherein routine operations change too much, thereby reducing the quality of work that is undertaken.

This study helps with the exploration of efficiency and satisfaction related to marketing and sales. Poorly performing areas and work stages not only raise awareness of the need for development, but also suggest avenues for individual career advancement and, with appropriate assistance, character development for those working in the field. A positive workplace atmosphere, supportive behavior, and respect for employees (even in the form of financial incentives) can result in more effective work that raises commitment.

The findings contribute to the design and development of corporate governance systems. Based on the above considerations, a more comprehensive study could be used to highlight areas of particular importance to the units that would facilitate its personalization, thereby increasing efficiency.

\section{Acknowledgments}

We would like to express our gratitude to Simon John Milton for proofreading this paper. 


\section{References}

Charmaz, K. (2006). Constructing Grounded Theory: A practical guide through qualitative analysis. Sage Publications, Thousand Oaks, Wiltshire.

Dewsnap, B., \& Jobber, D. (2009). An exploratory study of sales-marketing integrative devices. European Journal of Marketing, 43(7/8), 985-1007.

Ernst, H., Hoyer, W. D., \& Rübsaamen, C. (2010). Sales, marketing, and research-and-development cooperation across new product development stages: implications for success. Journal of Marketing, 74(5), 80-92.

Fern, E. F. (2001). Advanced focus group research. Sage, Thousand Oaks, California

Glaser, B. G., \& Strauss A. (1967). The discovery of Grounded Theory: Strategies for qualitative research. Hawthorn, New York.

Homburg, C., \& Jensen, O. (2007). The thought worlds of marketing and sales: which differences make a difference? Journal of Marketing, 71(3), 124-142.

Homburg, C., Alavi, S., Rajab T., \& Wieseke, J. (2017). The contingent roles of R\&D-sales versus R\&Dmarketing cooperation in new-product development of business-to-business firms. International Journal of Research in Marketing, 34(1), 212-230.

Johnson, J. S., \& Boeing, R. (2016). A União Faz a Força (There is strength in unity): understanding the salesmarketing interface in Brasil. Journal of Personal Selling \& Sales Management, 36(2), 190-205.

Karlíček, M., Chytková, Z., Tyll, L., \& Mohelská, H. (2014). Barriers of marketing effectiveness and efficiency within companies: a qualitative study. Economics and Management. 17(4), 111-124.

Kelly, S. J. (2017). How do sales and marketing produce business to business value propositions? Doctoral dissertation, Sheffield Hallam University, Sheffield, United Kingdom.

Keszey, T. (2014). Az értékesítés és a marketing kapcsolatának piaci tájékozódásban betöltött szerepe és meghatározó tényezői. [The role of sales and marketing relationship in market orientation and its determining factors]. Vezetéstudomány, 45(3), 39-48.

Keszey, T., \& Biemans, W. (2015, January). Antecedents and outcomes of sales-marketing encroachment. In ISPIM Conference Proceedings. The International Society for Professional Innovation Management (ISPIM).

Keszey, T., \& Katona, Á. (2016). Értékesítés és marketing részlegek együttmüködésének hatása a termékfejlesztésre. [The joint contribution of sales and marketing to new product development.] In: Fehér A., Kiss V. Á., Soós M., Szakály Z. (ed.). Hitelesség és értékorientáció a marketingben. Debreceni Egyetem Gazdaságtudományi Kar, 599-607.

Keszey, T., \& Katona, Á. (2017). Az értékesítők az új marketingesek? Avagy a marketing hatalmának hatása az értékesítés szerepére a termékfejlesztésben. [Are sales managers the new marketing managers? In other words: the effect of the power of marketing on the role of sale in product development.] In: Bányai E., Lányi B. \& Törőcsik M. (ed.) (2017): Tükröződés, társtudományok, trendek, fogyasztás. Pécsi Tudományegyetem, Közgazdaságtudományi Kar: Pécs. 543-551.

Kidd, P. S., \& Parshall, M. B. (2000). Getting the focus and the group: enhancing analytical rigor in focus group research. Qualitative health research, 10(3), 293-308.

Kotler, P. (2004). Ten Deadly Marketing Sins: Signs and Solutions. John Wiley and Sons, Hoboken, New Jersey.

Kotler, P., Rackham, N., \& Krishnaswamy, S. (2006). Ending the war between sales and marketing. Harvard Business Review, 84 (7/8), 68-76.

Knodel, J. (1993). The design and analysis of focus group studies: A practical approach. In: Morgan, D. L. (1993): Successful focus groups: Advancing the state of the art, part 1, 35-50.

Le Meunier-FitzHugh, K., \& Piercy, N. F. (2007). Exploring collaboration between sales and marketing. European Journal of Marketing, 41(7/8), 939-955.

Malshe, A., \& Biemans, W. G. (2015). Improving Sales and marketing collaborations; a step-by-step guide. Business Expert Press, New York.

Malhotra, N. K., \& Birks, D. F. (2007). Marketing research: An applied approach. $3^{\text {rd }}$ European ed., Prentice Hall, London 
Miles, M. B., \& Huberman, A. M. (1994). Qualitative Data Analysis: An expanded source book. Sage Publications, Thousand Oaks, California.

Micevski, M. (2015). Marketing and sales interface flexibility: a social exchange theory perspective. Doctoral dissertation, Loughborough University, Loughborough, United Kingdom.

Rabiee, F. (2004). Focus-group interview and data analysis. In Proceedings of the nutrition society, 63(4), 655660.

Rout, E. L., \& Omiko, N. (2007). Corporate conflict management: Concepts and skills. PHI Learning Pvt. Ltd., New Delhi.

Watson, K. R. (2017). Determining best practices for integrating marketing and sales in organizations: using the Delphi technique (Doctoral dissertation, Colorado State University. Libraries). 